\title{
Municipal Solid Waste Disposal Site Selection in Jacobabad Using RS/GIS Techniques
}

\author{
Saba Zehra1, Sheeba Afsar"2, Yasmeen Anis ${ }^{2}$ \\ ${ }^{1}$ Municipal Services Delivery Program, Karachi, Pakistan \\ ${ }^{2}$ University of Karachi, Karachi, Pakistan \\ Email: ssabazehra@gmail.com, sheebanaeem@hotmail.com, yanis@uok.edu.pk
}

How to cite this paper: Zehra, S., Afsar, S., \& Anis, Y. (2019). Municipal Solid Waste Disposal Site Selection in Jacobabad Using RS/GIS Techniques. Journal of Geoscience and Environment Protection, 7, 13-22. https://doi.org/10.4236/gep.2019.710002

Received: March 12, 2019

Accepted: October 13, 2019

Published: October 16, 2019

Copyright $\odot 2019$ by author(s) and Scientific Research Publishing Inc. This work is licensed under the Creative Commons Attribution International License (CC BY 4.0).

http://creativecommons.org/licenses/by/4.0/

\begin{abstract}
Solid waste management is a worldwide concern, particularly in the developing countries. The solid waste disposal and landfill site management is a serious issue. City planners and municipal corporations have to confront with the problem of Municipal Solid Waste Management all over the world, especially in the developing countries. Population growth is responsible for an increase in residential, commercial and infrastructure development, which poses adverse effects on the environment. One of the most serious and challenging environmental challenge being faced by the municipal corporations of developing countries is urban solid waste management. Dumping of municipal waste in unsuitable areas poses serious challenges to the local habitants of the neighborhood. Municipal solid waste, if not properly managed, is one of the major environmental issues that could further lead to different diseases' transmission, aesthetic and odor nuisance, and atmospheric and water pollution, etc. This paper aims to deal with the selection of suitable site for disposing off municipal solid waste management being produced at the Jacobabad City using Geographic Information Systems and Remote Sensing techniques. In the Jacobabad City, the existing open dumping systems are not environmentally sound posing serious environmental threats. Loads of generated waste (about 64 tons/day as per 2012 estimates) has been dumped into the inappropriate sites. Keeping in view the complicated process of landfill site, this study considers all the environmental, social and technical factors (distances from residences, proximity to road networks, schools, health facilities and reservoirs) to determine the best site for Municipal Solid Waste disposal in Jacobabad City. Different analysis like buffer analysis, Euclidean distance and overlay analysis were also performed in this study to come up with the most suitable landfill site.
\end{abstract}

\section{Keywords}

Solid Waste Management, Geographic Information System, Remote Sensing, Landfill Site 


\section{Introduction}

In developing countries, one of the challenging and tackling issues is selection and management of the appropriate solid waste dumping site because of the lack of proper solid waste management system, increased urbanization and population growth. Inappropriate practices of waste dumping without proper treatment into open and abandoned lands result in the serious health-related issues \& environmental pollution. According to Abbas et al. (2011), unsustainable waste disposal methods are caused by inadequate planning of solid waste management, resulting in the existing global trend of waste management issues. The designing of solid waste landfills must be done in a way that the environment gets protected from contaminants present in the stream of solid waste. One of the major problems that all over the world governments and city planners confront is municipal solid waste. According to Koshy et al. (2007), 35 million tons of municipal solid waste is estimated to be produced at United Kingdom annually, whereas more than 140 million tons municipal waste was generated in the United States annually. As per an estimate for Solid Waste Generation on the basis of population in 2004, Pakistan, with a population growth rate of about $2.61 \%$ per year, generate about 20,034,120 tons of Solid waste annually. Unfortunately, there is no proper solid waste management system in any city in Pakistan. The improper solid waste collection and disposal practices result in the clogging of drains and stagnant ponds' formation. These ponds serve as a breeding ground for mosquitoes and other insects which pose hazardous risks to public health in the form of cholera, malaria and dengue, etc. Therefore, there is a pressing need of implementation of proper waste management practices in order to confront the deteriorating situation of solid waste management in Pakistan.

In the developed countries, the effective solid waste management practices and process, including waste reduction, proper disposal and reuse recycle are used to effectively handle the solid waste. The immense population growth, increased industrialization, drastic urbanization, and waste generation in Pakistan calls for adoption of sustainable solid waste management system practices, techniques and policies like waste reduction, recycling, reuse, landfilling and thermal treatment. Novel strategies need to be developed for confronting waste management issues in a more generalized manner. Karadimas et al. (2004) put forward that integrated and computerized systems should be developed for acquiring more optimal solutions for urban solid waste management. That's why, this study aims to present the utility of GIS coupled with remote sensing techniques to select a proper solid waste disposal site preventing the siting of landfills in environmentally-sensitive areas. Information about the landfill site, and other associated features (slope, elevation, aspect, geology, soil etc.) can be extracted through the satellite remote sensing; this information can help in the selection of sites. For municipal solid waste management, GIS can serve as a decision support tool. GIS has the capability to store spatial datasets (like land-use, soil, population density, topography, hydrology, etc.) which can be helpful for determin- 
ing optimal route for transporting waste, planning points for waste collection \& disposal, \& selecting suitable waste disposal sites along with locating new landfills sites. This study is carried out to meet the below objectives:

- To create a GIS database for decision support system;

- To employ RS/GIS techniques to locate suitable potential location/s for landfill site in Jacobabad City through incorporating relevant criteria from environmental, social and spatial parameters.

\section{Study Area}

Jacobabad, located at $28^{\circ} 16^{\prime} 37.32^{\prime \prime} \mathrm{N}, 68^{\circ} 27^{\prime} 05.04^{\prime \prime} \mathrm{E}$, is the capital city of Jacobabad District, Sindh, Pakistan. The city has a total area of about $10.25 \mathrm{~km}^{2}$. It is subdivided into 8 Union Councils. The city is situated in the tropical and drought prone geographic zone. The groundwater of Jacobabad city is highly contaminated, brackish, and inappropriate for human consumption (Figure 1).

Based on the population data from 1998 census and projections of $3.18 \%$ annual increase population, the population of the 8 UC's in Jacobabad City has been projected for the year 2016 using the following formula (Table 1) (Figure 2):

$$
P f=P i(1+r / 100) n
$$

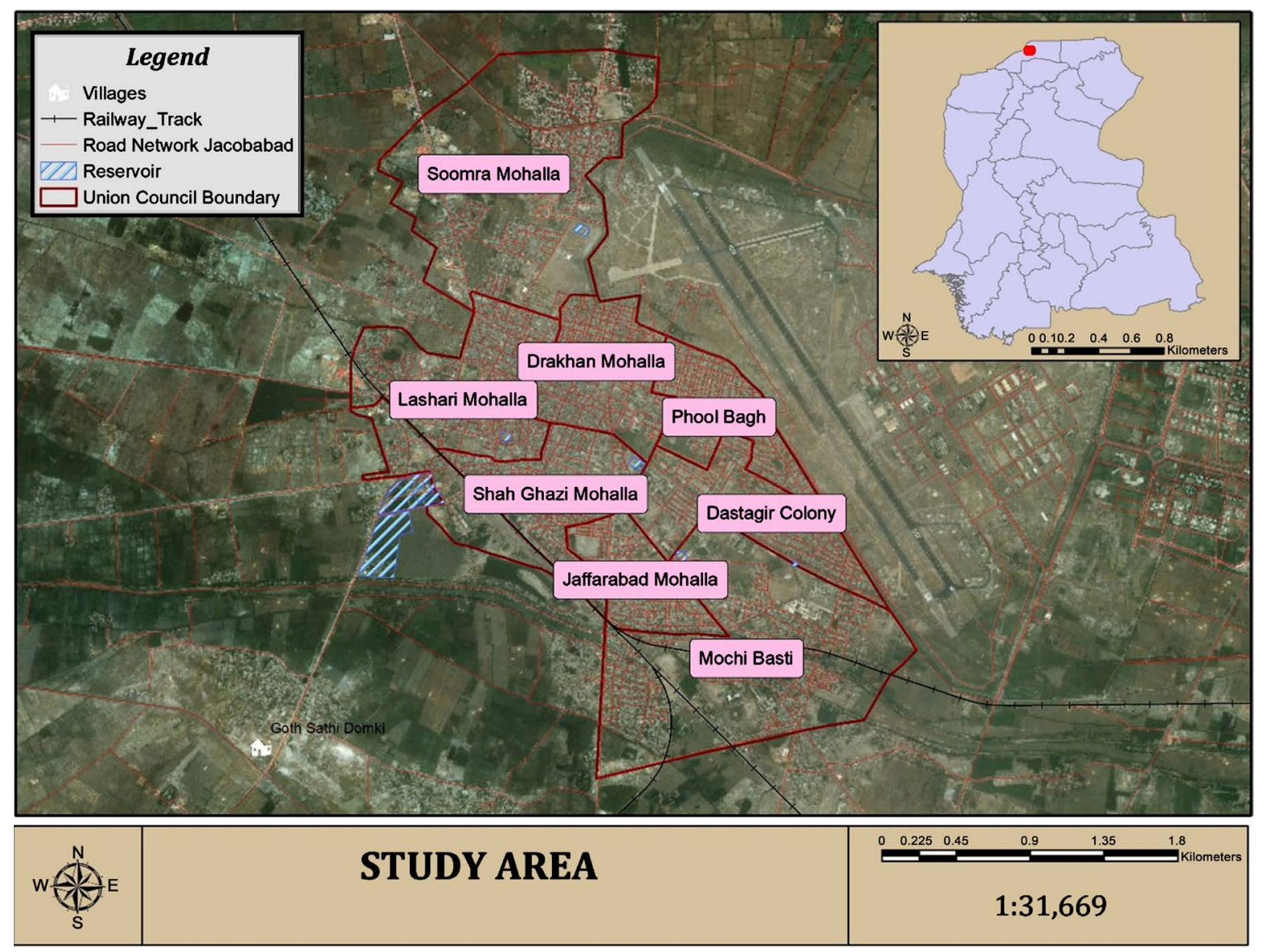

Figure 1. Study area. 
Table 1. Population of Union Councils in Jacobabad (Estimated 2016).

\begin{tabular}{ccc}
\hline S. No. & Union Council & Total Population \\
\hline 1 & UC-I Soomra Mohalla & 38,686 \\
2 & UC-II Lashari Mohalla & 42,013 \\
3 & UC-III Shah Ghazi Mohalla & 38,214 \\
4 & UC-IV Drakhan Mohalla & 38,167 \\
5 & UC-V Phool Bagh & 37,770 \\
6 & UC-VI Mochi Basti & 43,704 \\
7 & UC-VII Jaffarabad & 36,694 \\
8 & UC-VIII Dastgir Colony & 36,436 \\
& Total & $\mathbf{3 1 1 , 6 8 4}$ \\
\hline
\end{tabular}

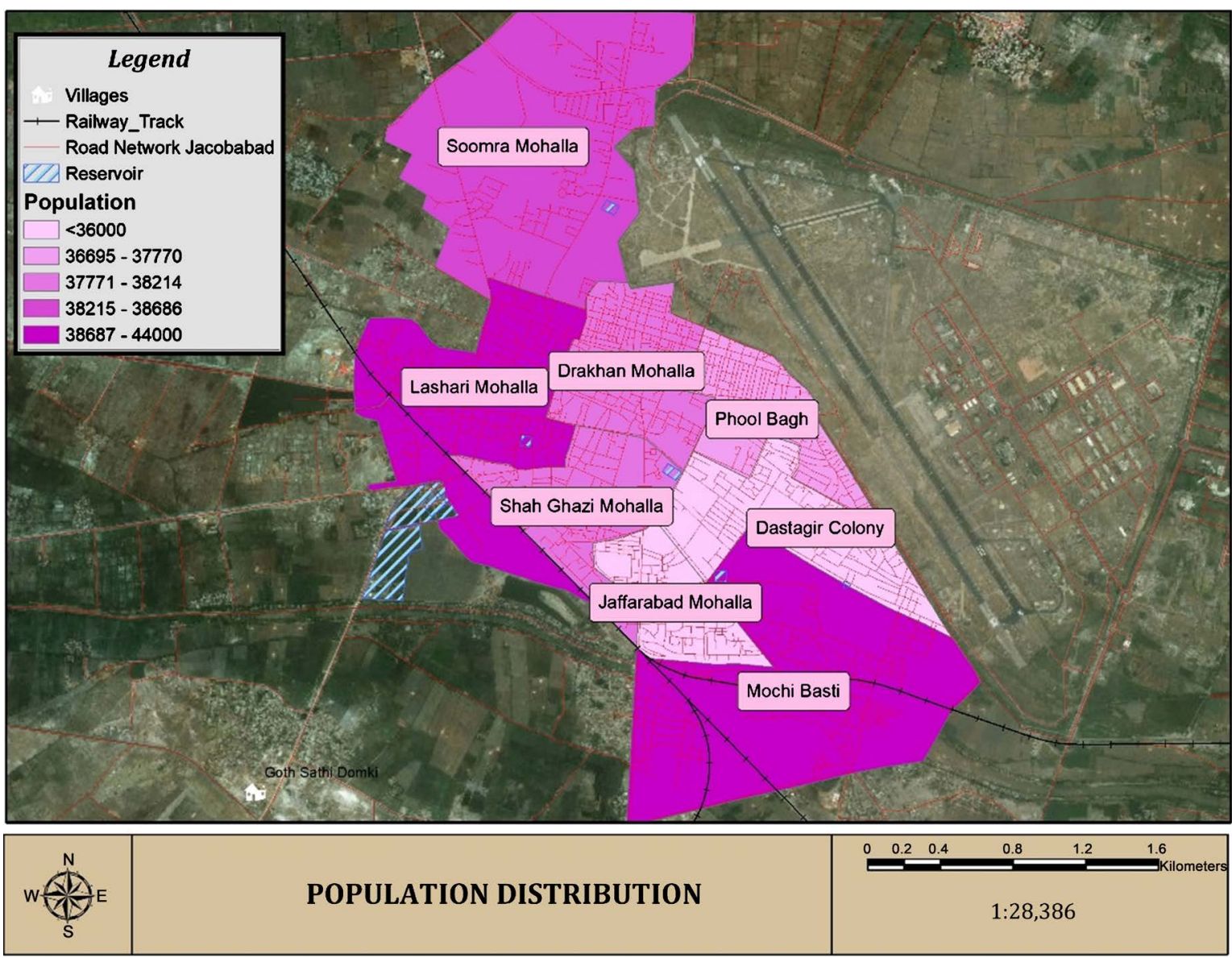

Figure 2. Population distribution of Jacobabad.

The population of Jacobabad City is estimated to be about 311,684.

In Jacobabad City, due to an increase in population and urbanization, the generated municipal solid waste has been substantially increased. An enormous concern in developing countries like Pakistan is municipal solid waste disposal as efficient wastes management is prevented in developing countries due to poverty, high urbanization rates, and population growth, in addition to under-funded \& 
ineffective governments. In Jacobabad, just like a number of other neglected urban centers and rural areas of Pakistan, the solid waste management system is in very poor condition. The rationale behind the improper Solid Waste Management in Jacobabad is rapid growth in population, lack of professional management and non-availability of required resource. Though currently some improvement projects have been jointly executed; however, there are still gaps and shortcoming in overall Solid Waste Management system in the Jacobabad city in many areas including lack of infrastructure and operational deficiencies. Tons of solid wastes are daily produced in the Jacobabad City from households, market centres, hospitals, offices, industry, etc. Below is an estimate of solid waste being produced by households (Table 2) (Figure 3).

\section{Methodology}

The solid waste management is not effective in the Jacobabad City, as we can see waste dumped almost all over the city, including roads, outside the houses, residential places, parks and grounds etc. Therefore, there is a pressing need that there must be some proper disposal sites in the Jacobabad City, where the collected Solid Waste can be properly disposed so as to avoid environmental degradation. The factors we use in this study in locating an environmentally friendly and a risk-free waste disposal site include land use/land cover, proximity to roads, proximity to railway track, proximity to reservoirs, schools, parks, flood susceptible areas. The location of landfill site should be away from settlements and residential areas \& also far from the areas that are highly vulnerable to flooding. The site should also be away from areas that are susceptible to flooding because flooding could cause disposal waste washout into stream or groundwater \& it could be hazardous for the local aquifer, human health and the overall environment. It is important to note here that though slope is an important criterion for site selection; however, in the Jacobabad City, the slope is almost flat all over the city (as shown in Figure 4); therefore, it is not taken as a criteria for landfill site selection.

Table 2. Solidwaste being produced by Households in Jacobabad (Estimated 2016).

\begin{tabular}{cccc}
\hline S. No. & Union Council & Total Population & Total Weight (Ton/Day) \\
\hline 1 & UC-I Soomra Mohalla & 38,686 & 13.09 \\
2 & UC-II Lashari Mohalla & 42,013 & 14.76 \\
3 & UC-III Shah Ghazi Mohalla & 38,214 & 13.09 \\
4 & UC-IV Drakhan Mohalla & 38,167 & 13.09 \\
5 & UC-V Phool Bagh & 37,770 & 13.09 \\
6 & UC-VI Mochi Basti & 43,704 & 14.76 \\
7 & UC-VII Jaffarabad & 36,694 & 13.09 \\
8 & UC-VIII Dastgir Colony & 36,436 & 13.09 \\
& Total & 311,684 & Total
\end{tabular}




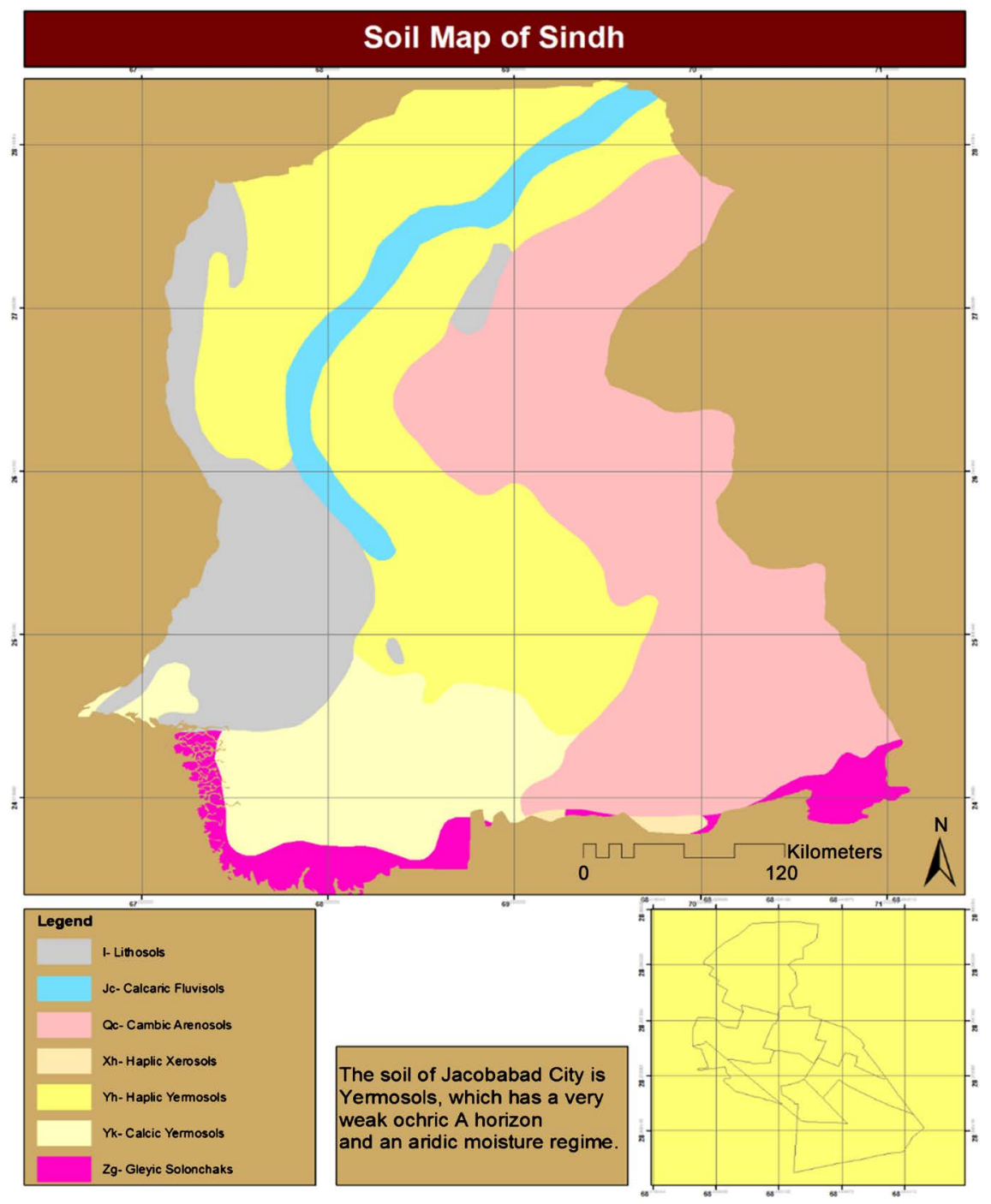

Figure 3. Soil of Sindh.

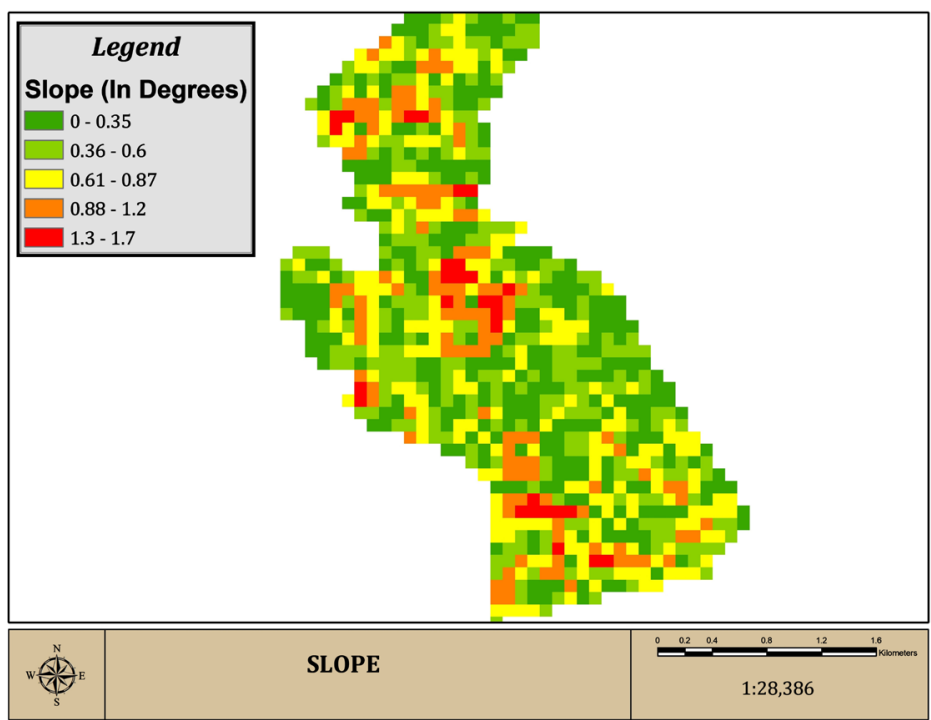

Figure 4. Slope of Jacobabad City. 
The methodology and the sequence of the steps taken to obtain the final deliverables are as under:

Setting of Criteria for landfill site selection
$\begin{aligned} & \text { Preparation of landuse map of the AOI using Landsat } 8 \\ & \text { images }\end{aligned}$
$\begin{aligned} & \text { Analysis of proximity to roads, railway track, schools, } \\ & \text { hospital, reservoirs and settlements }\end{aligned}$
$\begin{aligned} & \text { Generation of Binary Maps based on suitability \& non- } \\ & \text { suitability }\end{aligned}$
$\begin{aligned} & \text { Development of Final Candidate Map through overlaying } \\ & \text { all set criteria }\end{aligned}$

\section{Landsat Image Classification}

The Landsat 8 image of Jacobabad was obtained from

https://earthexplorer.usgs.gov/. The area was clipped and then the image was processed in Erdas Imagine 2014. The image is classified into 4 classes of Vegetation, Agriculture, Barren Land and Settlement. Below is the classified image of Jacobabad City (Figure 5).

\section{Results and Discussion}

It is not an easy task to select potential landfill site for waste disposal as careful and an evaluation of the study area is required so as to determine the optimal available waste disposal location. Environmental, economic, and social factors need to be considered while landfill site selection. The criteria selected for this

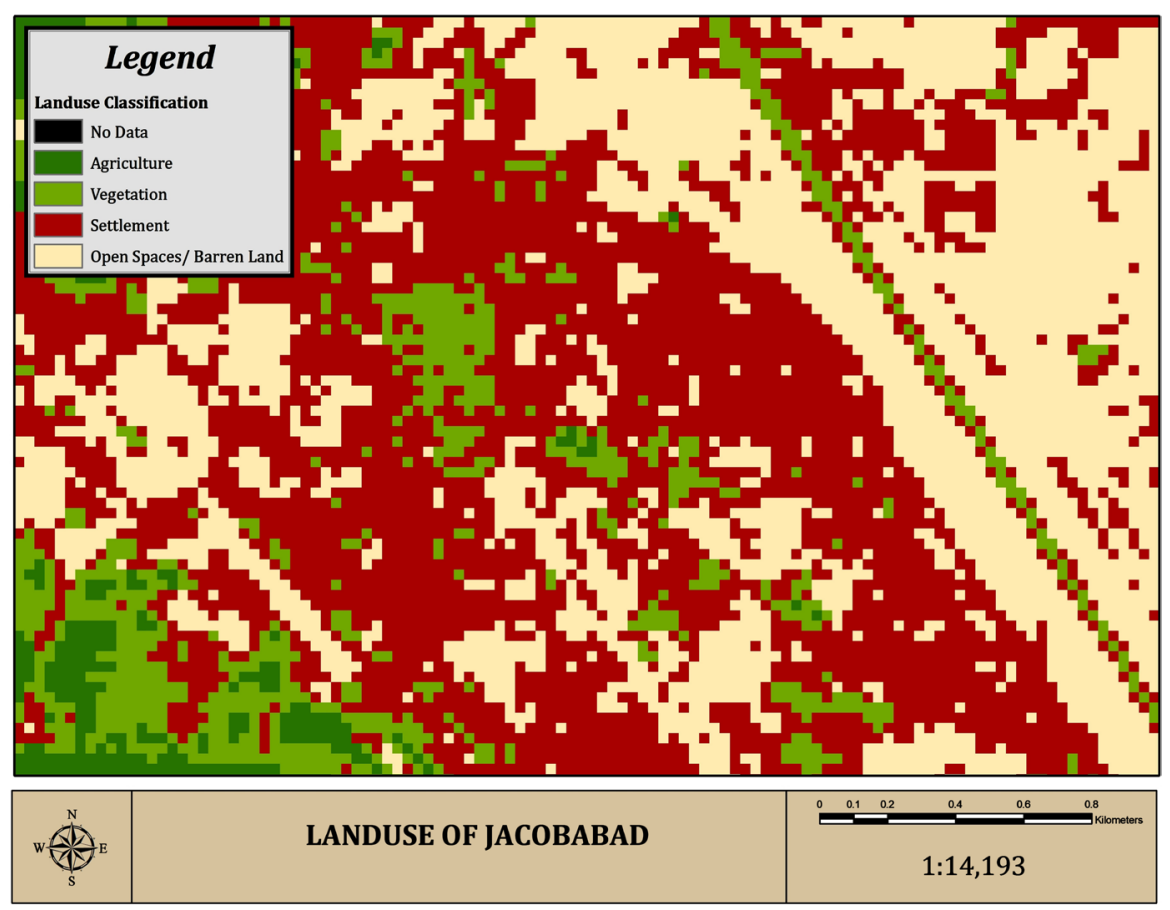

Figure 5. Landuse of Jacobabad. 
study are discussed below:

\section{1) Residential Areas}

The landfill site should not be located very near to the settlements and highly dense areas as these sites decrease the value of real estate, and pose environmental (odor, noise) and health risks. As per EPA (2006) specifications, the landfill sites should be located in an area which is at a considerable distance from residential or commercial areas. In order to perform the suitability analysis, the land use map of the Jacobabad City was developed and then reclassified into suitable and non-suitable areas (Figure 6).

\section{2) Proximity from the Roads}

Proximity from the roads is an important criteria for locating landfill site as if the landfill site will be located close to a road then it will damage the aesthetic value of that area. However, locating landfill site too far away from the existing road network will result in increased costs for both collection \& transportation of solid waste. Buffer zones were created around the major and minor roads. It is

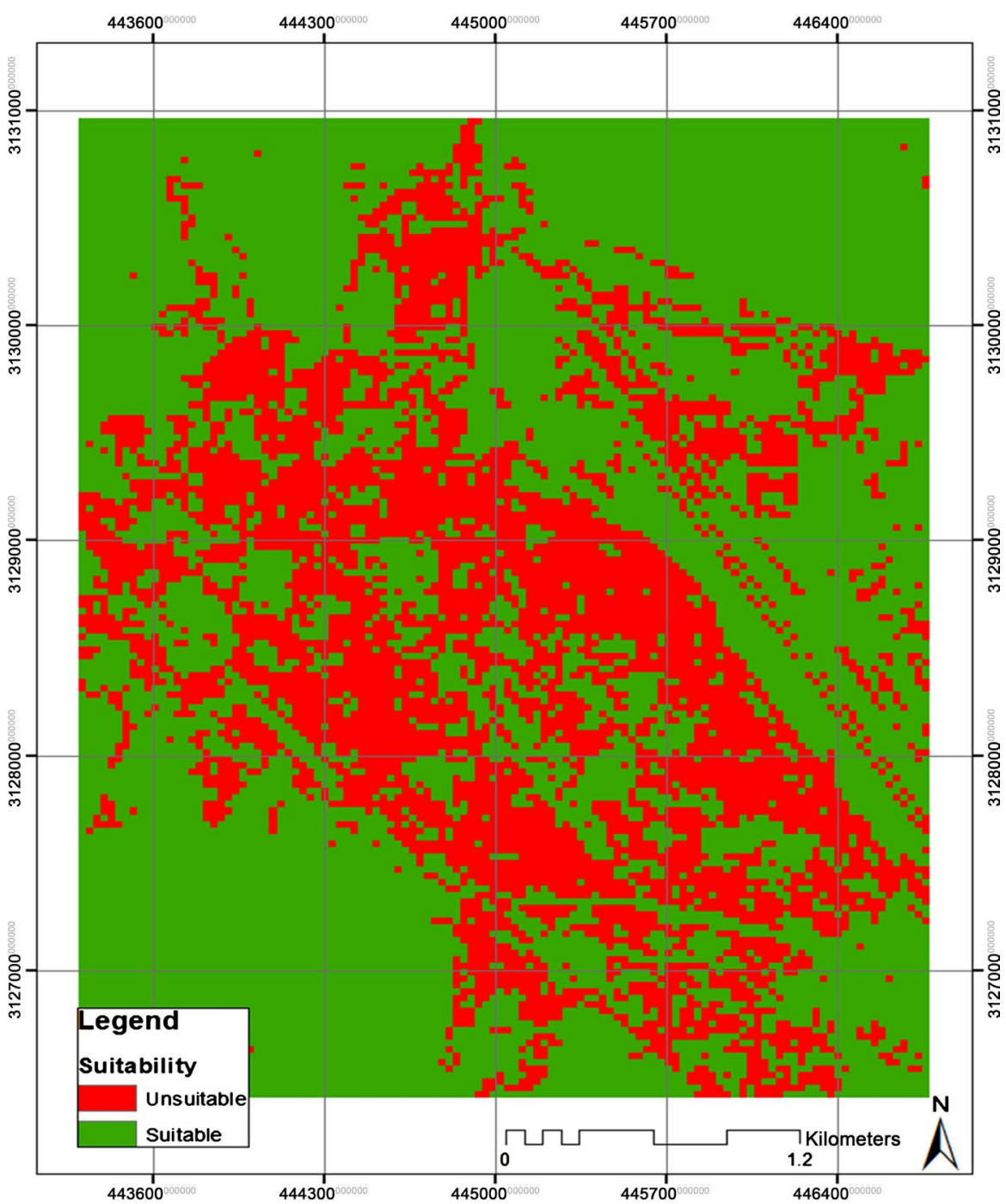

Figure 6. Reclassification of landuse. 
found, for this study, that a buffer of hundred meter is sufficient for aesthetic value and to optimize possible sites.

\section{3) Proximity from the Railway Track}

Landfill site should not be located within 100 meters of any transportation routes like railway track, major highways etc. Buffer zone of 100 meter was made around the railway track.

\section{4) Proximity to Water Reservoirs}

It is quite unsuitable to locate a landfill site around the water (river, stream, canal, reservoir, etc.), as the contaminants could flow into the water. Therefore, a buffer zone of 200 meters was made around the water reservoirs.

\section{5) Proximity to School \& Other Infrastructure}

A $200 \mathrm{~m}$ buffer is created around school areas and hospitals.

Once all the criteria are defined and mapped out then the overlay analysis was carried out followed by the dissolve process. Eventually, a final map of suitable landfill site was developed (Figure 7).

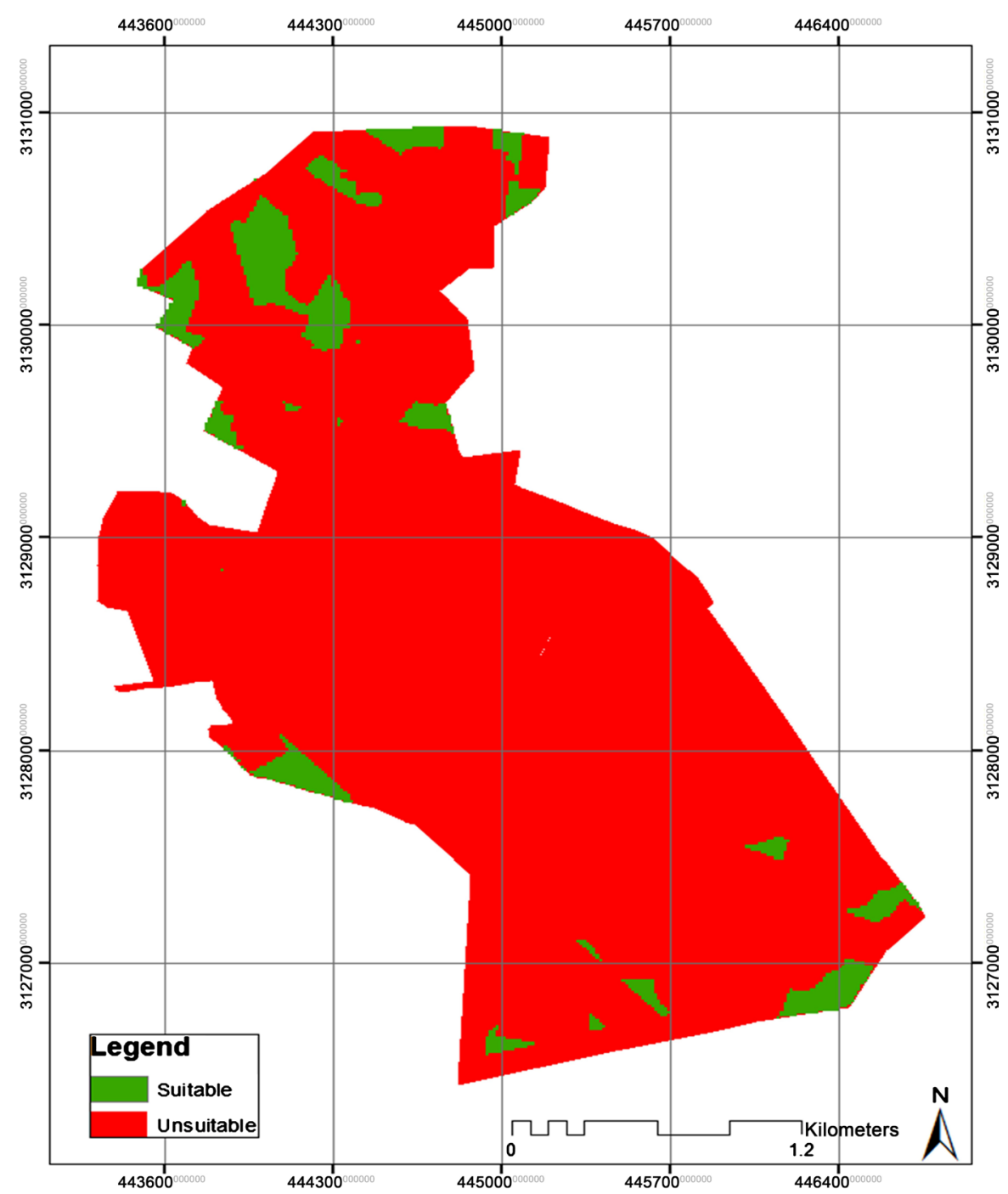

Figure 7. Suitable \& unsuitable areas for landfill site. 


\section{Conclusion}

Suitable landfill site selection is a crucial aspect of urban planning. This paper attempted to demonstrate the effectiveness of RS/GIS techniques for decision support. In the siting process of landfill, many factors and criteria need to be evaluated. This study considers environmental as well as social factors (distances from residences, proximity to road networks, schools, health facilities and reservoirs) to determine the best site for Municipal Solid Waste disposal in Jacobabad City. Considering different landfill site selection criteria, the areas satisfying the minimum requirements for the landfill site selection are mapped out. However, in order to select the final municipal solid waste site, geotechnical and hydrogeological analyses of the site need to be done so that any impact of landfills on the groundwater and surface water can be mitigated.

\section{Conflicts of Interest}

The authors declare no conflicts of interest regarding the publication of this paper.

\section{References}

Abbas, I. I., Nai'ya, R., \& Arigbede, Y. A. (2011). Use of Remote Sensing and GIS in Effective and Efficient Solid Management Planning (a Case Study of Samara, Zaria, Nigeria). Research Journal of Earth and Planetary Studies, 2, 46-52.

EPA (2006). EPA Landfill Manuals Manual on Site Selection Draft for Consultation. Environmental Protection Agency.

Karadimas, N. V., Loumos, V., \& Mavrantza O. (2004). Quality of Service Ensuring in Urban Solid Waste Management. In Proceeding of the 2nd International IEEE Conference on Intelligent Systems (Vol. 1, pp. 288-292). Varna.

Koshy, L., Emma, P., Sarah, L., Tim, J., \& Kelly, B. (2007). Bioreactivity of Leachate from Municipal Solid Waste Landfills-Assessment of Toxicity. Science of the Total Environment, 384, 177-181. https://doi.org/10.1016/j.scitotenv.2007.06.017 